\title{
Different Responsibilities of Physical Education Teachers in Urban and Suburbs in Implementing Distance Learning
}

\author{
Ermawan Susanto ${ }^{1, *}$ Dimyati Dimyati ${ }^{1}{ }^{1}$ Komarudin Komarudin ${ }^{1}$ Joko Purwanto ${ }^{1}$
}

\author{
${ }^{1}$ Universitas Negeri Yogyakarta, Indonesia \\ ${ }^{*}$ Corresponding author.Email: ermawan@uny.ac.id
}

\begin{abstract}
The implementation of physical education (PE) has the potentially will not run optimally because it is implemented through distance learning. PE teachers have a heavy responsibility in implementing distance learning. This study aims to determine the differences in the responsibilities of PE teachers in urban and suburban areas of the Special Region of Yogyakarta. The method used is experimental pre-test and post-test. The study population was PE teachers in urban and suburban areas who carried out distance learning $(n=60)$. The instrument used is a modification of the Tool for Assessing Responsibility-Based Education (TARE), consisting of 28 questions about teacher responsibilities. Primary data collection by questionnaire and secondary data collection by literature study. The results of the data independence $\mathrm{t}$-test analysis showed that the significance value was .000<.01 (confidence interval $=99 \%$ ), the results of the paired sample t-test data analysis showed that the significance value was $.000<.01$. Thus the results of the study indicate that the responsibility of teachers in urban areas is higher than that of teachers in suburban areas. The attitude of teacher responsibility is considered as one of the feasible and effective pedagogical approaches for the distance learning.
\end{abstract}

Keywords: Responsibility, Physical Education, Distance Learning, Urban and Suburban, Teacher.

\section{INTRODUCTION}

The Indonesian government stipulates that distance learning is carried out during the COVID-19 pandemic. Learning that is usually carried out face-to-face has turned into distance learning. Physical education (PE) teachers who previously served as direct teachers, have a dual role as distance learning operators [1]. This situation becomes difficult for teachers and students, as well as a challenge in carrying out the new order of education [2]. In the context of learning in schools, the responsibility of teachers is absolutely necessary to fulfill their obligations as teachers and educators. During this pandemic period, teachers are directed to carry out distance learning in a network with an online system [3].

PE becomes a complicated lesson when carried out remotely, which means that learning is carried out with the help of technology and carried out with the dimension of distance. Physical activity is no longer monitored and measured directly but is monitored remotely and measured independently. This condition will certainly make it difficult to acquire the right fundamental skills and the right activities. However, PE distance learning will not be optimal. What happened during this pandemic made teachers have to remain fair in delivering learning material with a dominant focus on the psychomotor domain. Because the learning process during the pandemic there has been a shift from the motor domain to the dominance of the cognitive domain [4]. Thus, the purpose of PE lessons has shifted from the demands of fulfilling physical fitness to only aspects of knowledge.

To carry out distance learning requires qualified supporting facilities. Good learning should provide adequate learning facilities, including study rooms, adequate lighting, handbooks, completeness of equipment [5]. So in this case, distance learning facilities are everything that should make it easier to learn. However, not all students have adequate facilities. For example, do not have a smartphone or laptop, low purchasing power of internet quota and no free internet network available [6]. The survey results show that $29 \%$ of Indonesia's population does not have a mobile phone. As many as $28 \%$ of the population have ordinary cellphones but cannot support the implementation of elearning while those who have smartphones are only $42 \%$ [7]. The Ministry of Education reported that $40.5 \%$ of 
students' parents had problems with the lack of learning support facilities.

For the effectiveness of online learning, it is necessary to use various media or applications. The learning process is experiencing obstacles such as having difficulty doing assignments, not knowing how to use learning applications such as zoom, google classroom, google meeting and the like, resulting in students being left behind in learning understanding [8]. Unstable network is also an obstacle in the learning process with the system in the network. The existence of network facilities is the main thing in system learning in the network, because it is related to the smooth learning process. The existence of students who are far from the city center or far from the reach of the provider network certainly cannot carry out the learning process smoothly. This problem is experienced by many students who live in suburban areas. This results in learning activities that are not optimal. The key to online learning is students' independence to learn [9]. Therefore, independence is very important in the learning process during this pandemic. These obstacles require the teacher's responsibility.

According to Burges' concentric theory of urban spatial structure, the area is divided into regions. The urban area is referred to as the Central Business District (CBD), which is the city center which is located right in the middle of the city and is circular in shape which is the center of social, economic, cultural, educational, and political life, tends to have a pattern of rational, economic and individualistic relationships and is a zone with a high degree of high accessibility in a city [10]. On the other hand, there is a suburban area which is a hinterland or a suburban boundary, the population working in the city and living in the suburbs or working in the suburbs. By paying attention to the theory of urban spatial structure, it can be understood that access to education is also different which of course will affect the responsibility of teachers in carrying out education. In this study, the urban area is the City of Jogja, which is an educational center with excellent access to education. The outskirt area is Gunungkidul Regency which is the farthest district from the city center with most of the mountainous areas and low access to education. These two cities are located in the Special Region of Yogyakarta Province.

In the aspect of PE facilities and infrastructure, it is also far from ideal considering that learning support tools and facilities cannot be provided by each individual. This condition is certainly a problem because PE learning is very closely related to sports facilities and infrastructure. On the one hand, students are expected to maintain good physical fitness during distance learning. This condition can be done by exercising regularly using low-moderate exercise intensity [11]. Physical activity can be done at home even without the need to use complex equipment. Based on this, PE teachers need to prioritize responsibility in distance learning to achieve positive results, one of which has been shown internationally through the Teaching Personal \& Social Responsibility model [12].

The responsibility teaching model aims to increase responsibility in movement learning and prevent problematic behavior [13]. Based on this, PE teachers need to use appropriate instructional approaches to achieve positive results. The responsibility teaching model was created to teach responsibilities such as respect for others, empathy, self-control, independence, caring and leadership skills. This model is used as an alternative to $\mathrm{PE}$ teaching which aims to promote a responsible attitude towards the profession as a teacher and is a learning tool that teaches skills in social life and promotes a responsible attitude.

In the end, this study was intended to determine the responsibilities of teachers as professional teachers in implementing distance learning during the COVID-19 pandemic. Mastery and renewal of materials, learning innovations, social skills, and challenges facing different geographical areas are actualized in the noble task of learning by adjusting to the demands of the times.

\section{STYLE PALETTE}

The research design used was experimental pre-test \& post-test with a control group. The control group does not mean not given any treatment, but serves as a comparison to prove something. The instrument for measuring responsibility uses the Tool for Assessing ResponsibilityBased Education. The number of questionnaire items is 28 items with a validity level of 0.74 and a reliability of 0.98 .

Table 1. Research design

\begin{tabular}{|l|l|}
\hline \multicolumn{1}{|c|}{ Experiment } & \multicolumn{1}{c|}{$\begin{array}{c}\text { Independence t-tes \& paired } \\
\text { sample t-test }\end{array}$} \\
\hline Pre-test & Questionnaire with 28 questions \\
\hline Intervention & Distance learning for 8 weeks \\
\hline Post-test & Questionnaire with 28 questions \\
\hline Participants & 30 PE teachers in urban \\
\hline Participants & 30 PE teachers in suburban \\
\hline
\end{tabular}

\subsection{Participants}

The research participants were 30 junior high school PE teachers who carried out distance learning in urban areas (Teachers Association in the City of Jogja) and 30 junior high school PE teachers who carried out distance learning in suburban areas (Teachers' Association in Gunungkidul Regency). The research sample was selected by cluster random sampling. The experimental test was in the form of distance learning and carried out for 10 weeks. The research was carried out in FebruaryJuly 2021. 
Table 2. Distance learning intervention test

\begin{tabular}{|c|l|c|}
\hline Sesion & \multicolumn{1}{|c|}{ Material } & Platform \\
\hline 1 & Softball & Zoom \\
\hline 2 & Martial arts & Zoom \\
\hline 3 & Physical fitness & Zoom \\
\hline 4 & Gymnastic & Zoom \\
\hline 5 & Aerobic & Pilot Project \\
\hline 6 & Swimming breaststroke & Pilot Project \\
\hline 7 & Hiking & Pilot Project \\
\hline 8 & Health education \\
\hline
\end{tabular}

\subsection{Data Collection}

Collecting data in the form of primary data and secondary data. Primary data using a questionnaire. Secondary data obtained by conducting a literature study. The data collection procedure is that the researcher selects the PE subject materials that will be taught in the zoom meeting platform in accordance with the $7^{\text {th }}$ grade junior high school curriculum. Next, the researcher conducts trials of PE subject materials and research instruments to non-respondents and corrects invalid instruments. Implementation of experiments which include: (a). Giving directions to the teacher for filling out the questionnaire; (b). Measurement of the pre-test of the attitude of responsibility for approximately 30 minutes. (c). Implement distance learning for 8 weeks. d. Measurement of the post-test of attitudes for 30 minutes. The teacher responsibility questionnaire is as follows:

Table 3. Teacher responsibilities questionnaire

\begin{tabular}{|l|l|}
\hline Factors & \multicolumn{1}{c|}{ Indicator } \\
\hline \multirow{4}{*}{ Pedagogy } & Planning the organization of teaching \\
\cline { 2 - 2 } & Planning the management of teaching \\
\cline { 2 - 2 } & Planning an assessment \\
\cline { 2 - 2 } Professional & Planning the use of teaching media \\
\hline \multirow{4}{*}{ Social } & Professional development \\
\cline { 2 - 2 } Personality & Insightful understanding \\
\cline { 2 - 2 } & Mastery of academic study materials \\
\cline { 2 - 2 } & Communicate \& interact with students \\
\hline & Communicate \& interact with teachers \\
\hline & Pommunicate \& interact with community \\
\cline { 2 - 2 } & Manning the learning process \\
\hline
\end{tabular}

\subsection{Data Analysis}

Data analysis using independent t-test to see the difference between the experimental group and the control group through the significance value on the t-test. Analysis of paired t-test data to see the difference between the results of the initial test scores and the results of the final test scores through the significance value on the t-test. Prerequisite test includes normality test and homogeneity test.

\section{FINDINGS}

This study used an experimental method which was divided into two groups, namely teachers in urban areas and in suburban areas with distance learning intervention of PE subject materials for $7^{\text {th }}$ grade junior high school students.

Table 4. Mean scores and significance of teacher responsibilities in urban and suburban areas

\begin{tabular}{|c|c|c|}
\hline Group & Pre-test average & Post-test average \\
\hline Urban area & $6.5^{*}$ & $10.3^{*}$ \\
\hline Suburban area & 5.3 & 6.2 \\
\hline$* \mathrm{p}<0.5$ (real different); ${ }^{*} \mathrm{p}<0.1$ (very real different)
\end{tabular}

\subsection{Hypothesis Testing}

Based on the hypothesis test, the following results were obtained:

Table 5. Analysis of paired sample test results for urban and suburban groups

\begin{tabular}{|c|c|c|c|c|c|}
\hline & & \multicolumn{3}{|c|}{ Paired Differences } & \multirow{2}{*}{ t } \\
\cline { 3 - 5 } & & Mean & SD & SE & \\
\hline Pair 1 & $\begin{array}{c}\text { Pre-post test } \\
\text { Urban Area }\end{array}$ & -7.137 & 5.385 & .983 & -7.540 \\
\hline Pair 1 & $\begin{array}{c}\text { Pre-post test } \\
\text { Urban Area }\end{array}$ & -8.321 & 9.352 & 1.707 & -4.631 \\
\hline
\end{tabular}

$\mathrm{SD}=$ Standart Deviasi, $\mathrm{SE}=$ Standart Error of Mean

\subsection{Normality Test}

To test the hypothesis, prerequisite tests were carried out which included tests of normality and homogeneity which can be seen in Tables 6 and 7. Before conducting data analysis, it is necessary to meet the analysis requirements to prove that the data are normally distributed. To find out, it is proven by normality test. The results of the analysis of the normality test of the data in Table 6 show that the variable values in urban and suburban areas, both pre-test and post-test values are normally distributed.

Table 6. Normality test results

\begin{tabular}{|c|c|c|c|c|}
\hline Experiment group & K-s Test & P-value & Distribution \\
\hline Urban & Pre & 0.557 & $>0.05$ & Normal \\
\hline & Post & 0.570 & $>0.05$ & Normal \\
\hline Suburban & Pre & 0.621 & $>0.05$ & Normal \\
\hline & Post & 0.896 & $>0.05$ & Normal \\
\hline
\end{tabular}

To confirm the results of the difference in the increase in teacher responsibility, an independent t-test was conducted by comparing the post-test results of teachers in urban and suburban areas. Researchers used the Kolmogorov-Smirnov Test with 60 respondents. The significance shows that $.570>.005$ and $.0896>.005$ so that the data can be stated that the experimental group is normally distributed. The hypothesis formulated by the researcher is H0: There is no difference in distance learning to the final score of teachers in urban and suburban areas. H1: There is a difference between distance learning and the final score of teachers in urban and suburban areas. 


\subsection{Homogeneity Test}

Likewise, before data analysis, it is necessary to meet the analysis requirements to prove that the data is homogeneous. To find out, it is proven by homogeneity test. The results of the analysis of the homogeneity of the data in Table 7 show that the urban and suburban groups have both pre-test and post-test values which show homogeneous distribution.

Table 7. Normality test results

\begin{tabular}{|c|c|c|c|c|}
\hline \multicolumn{2}{|c|}{ Experiment group } & $\begin{array}{c}\text { Levene } \\
\text { Statistic }\end{array}$ & Probability & Varian \\
\hline Urban & Pre & 0.540 & $>0.05$ & Homogen \\
\hline & Post & 0.212 & $>0.05$ & Homogen \\
\hline Suburban & Pre & 0.631 & $>0.05$ & Homogen \\
\hline & Post & 0.222 & $>0.05$ & Homogen \\
\hline
\end{tabular}

In the results of the independent sample t-test, the Levene test was carried out which was used to see how the data assumptions were obtained. The significance result of Levene's test shows that $.212>.05$ then the data variance is assumed to be the same. The results of the $t$ test showed that there was a significant difference between groups of teachers in urban and suburban areas because the significance value was $.022>.05$. This illustrates that the level of teacher responsibility in urban and suburban areas is homogeneous or equal.

\subsection{Teacher Responsibilities in Urban Area}

The responsibility of teachers in urban areas in implementing distance learning is seen from the initial process of the experiment, namely analyzing the respondents' initial tests by measuring the pre-test before being given distance learning. The teacher's responsibility before being given treatment based on Table 4 in the urban group shows the number 6.5 is included in the medium category. The average group of teachers in urban areas is 10.2 , so it can be concluded that groups of teachers in urban areas are more responsible for implementing distance learning compared to groups of teachers in the suburban area. These results indicate that teachers in urban areas are prepared to be given distance learning. This alternative distance learning can be developed by teachers in urban areas so that PE learning can run smoothly. Next, an independent sample t-test was conducted to determine whether the difference in the initial test of respondents' responsibilities was significant or not.

After conducting initial tests on respondents, groups of teachers in urban and suburban areas were given distance learning. Next, a final test was conducted to determine whether there was an increase in the score from the initial test and the final test. The results of the difference in the scores of the initial test and the final test, it is found that the score of the respondents increased in the groups of teachers in urban and suburban areas.
Increased responsibility in urban areas by 3.6 or $54.5 \%$ while in the suburban area by 0.85 or $15.9 \%$.

In Table 5, the results of the paired hypothesis test in the urban group show .754 $>.01$ and the sub-urban group shows $.463>.01$, then the variance of the data is assumed to be equal. The next step is to see how paired t-test can answer the formulated hypothesis. By looking at the equal variances assumed, the significance results show that $.000<.01$ (confidence interval $=99 \%$ ) then $\mathrm{H} 0$ is rejected. It is evident that there is a very significant difference in distance learning to the final scores of teachers in urban and suburban areas.

To see the significance of the increase in responsibility, a paired sample t-test was conducted which compared the mean scores of the initial and final tests of each group. The test results showed that there is a very significant difference because the significance value is $.000<.01$. This illustrates that the increase in responsibility in urban areas is high after implementing distance learning of PE lessons.

\subsection{Teacher Responsibilities in Suburban Area}

The teacher's responsibility before being given treatment based on Table 4 in the suburban group of 5.3 is included in the low category. The mean in the periphery teacher group is 6.2 , which means that the suburban teacher group is less responsible for implementing distance learning. Then, an independent sample t-test was conducted to determine whether the difference in the initial test of respondents' responsibility was significant or not. Distance learning for groups of teachers on the suburban faces many obstacles related to technological readiness, readiness of teaching staff, enthusiasm of students, and relatively expensive costs so that distance learning of PE is not optimal.

In Table 5, the results of the paired hypothesis test in the urban group show $.754>.01$ and the suburban group shows $.4 .631>.01$, then the variance of the data is assumed to be equal. By looking at the equal variances assumed, the significance results show that $.000<.01$ (confidence interval $=99 \%$ ) then $\mathrm{H} 0$ is rejected. It is proven that there is a very significant difference in terms of teacher responsibilities in implementing distance learning to the final score of teachers both in urban and suburban.

From the results of the test of the teacher responsibility hypothesis on the suburban, it shows that there is no difference between the initial and final test scores because the significance value is $.184>.05$. This illustrates the opposite situation than in urban areas, where it turns out that the responsibility of teachers in the suburbs does not increase after implementing distance learning. 


\section{DISCUSSION}

\subsection{Teacher Responsibilities in Urban Area}

The main objective of this study was to determine the differences in teacher responsibilities from an 8-week distance learning intervention in PE lessons. The results of this study support the hypothesis that there are differences in teacher responsibilities in urban and suburban groups. These results are consistent with research on change that can be proven through an attitude of responsibility. The attitude of responsibility can occur because distance learning is influenced by the professionalism of teachers even though they are in urban areas that have good access to education and in suburban areas that have less access to education [14]. PE lessons are traditionally considered practical and "hands on" lessons in schools, where closeness and physical contact are common, so learning becomes more lively because of direct teaching. The distance learning in PE lessons is constrained by technological limitations that are against the nature of PE lessons themselves [15].

Based on the results of this study, there is a gap between education in urban areas and in the suburbs that have an impact on the implementation of distance learning, namely: access to schools; school facilities \& infrastructure and teacher resources. The results of the researchers' observations on these three factors, among others, are that the junior high schools in the city of Jogja are located in the downtown area of the Province of the Special Region of Yogyakarta. Educational facilities in the City of Jogja are also very advanced, marked by the existence of complete information technology devices and almost every junior high school. Geographically, the location of the area is also very strategic, being in the city center which is one with the center of government and is passed by a variety of public transportation that is widely used by the community to carry out activities [16]. So, students can easily get a lot of access to go to school.

School facilities and infrastructure are certainly very different. Schools in urban areas have complete school facilities and infrastructure. Learning support facilities ranging from libraries to laboratories are adequate and well maintained. Access to education in urban areas has been very well proven by human resources or teachers who have taken higher education [17]. Sources of teaching staff or PE teachers on average after taking master's education.

The results of the researcher's analysis related to the responsibility variable are related to the factors of teacher competence contained in four competencies, namely: pedagogy, professional, social, and personality. Pedagogy responsibility is a responsibility in terms of the ability or skills of teachers who can manage a learning process or teaching and learning interactions occur with students [18]. The pedagogical responsibility of teachers in urban areas can be seen in the teacher's ability to explain the material, implement learning methods, ask questions, answer questions, manage classes, and carry out structured and responsible learning evaluations. This can be seen in the final test of the questionnaire that has been distributed [19].

Professional responsibility is the responsibility in terms of skills, abilities, knowledge and skills possessed by an educator, teacher, mentor of students in the teaching and learning process. Groups of teachers in urban areas have professional competence in terms of mastery of the material, mastery of other science materials, and relevance to the subject matter of certain subjects. For example, PE teachers who teach the subject of football are not enough to master material related to basic football skills, but also must master and understand the rules of the games [20].

Social responsibility is the teacher's responsibility in terms of individual abilities to work together, build social interactions with the surrounding environment by using knowledge about themselves and being able to communicate well with empathy [21]. The social responsibility of teachers in urban areas is shown in terms of the position of the teacher who is still an elite figure in society who is considered to have considerable moral authority. One of the consequences for that role to remain inherent in the teacher is that the teacher must have the ability to relate and communicate with others.

Personal responsibility is the responsibility of personal abilities that reflect a steady, stable, mature, wise and authoritative personality, be an example for students, and have character [22]. The responsibility of the teacher's personality in urban areas appears in terms of teachers who are patient, calm, responsible, democratic, sincere, intelligent, respecting others, stable, friendly, assertive, brave, creative, and initiative.

\subsection{Teacher Responsibilities in Suburban Area}

The results of researchers' observations on access to schools, school facilities and infrastructure and teacher resources, it is known that junior high schools in the Gunungkidul Regency area are far outside the city center, precisely in the highlands and bordering coastal areas [23]. Access to school is quite far from where they live, so it becomes a separate obstacle for students. Some areas on the suburban have not been reached by telecommunication providers so that distance learning cannot be fully implemented [24]. The implementation of distance learning is less than optimal due to the nonfunctioning of the teacher's role as an instructor in directing the movement function for students. So that the development of movements or physical activities that are 
quite complicated becomes more complicated because there is no direct role model.

School facilities and infrastructure are also very different. Not all teachers and students have distance learning technology devices such as smartphones, PCs, or laptops, including internet networks. It is undeniable that there are teachers who have not been able to utilize learning media or learning platforms properly [25]. Schools in suburban areas do not have learning support facilities other than the field in front of the class which is usually used for PE lessons. Other infrastructure facilities to support learning are also very limited. The quality of education in suburban areas is still very limited, as evidenced by human resources or teachers who have not taken much further education. The average teaching staff in the suburbs has a bachelor's degree.

The results of the researcher's observations related to pedagogical responsibilities for groups of teachers in suburban areas can be seen in the teacher's ability to explain material, implement learning methods, ask questions, answer questions, manage classes, and carry out learning evaluations that are not yet fully structured. However, with this distance learning model, teachers have difficulty in implementing technology-based learning methods $[26,27]$.

Professional responsibility for groups of teachers on the suburban area can be seen in terms of mastery of the material, mastery of other current science materials, and linkages with the subject matter of certain subjects. However, there are still few teachers who upgrade their scientific materials, related to PE materials and sports science [28]. So that the professional responsibilities of teachers in the suburbs are still stagnant.

The social responsibility of teachers in the suburbs is shown in terms of the position of the teacher who is still an elite figure in society who is considered to have considerable moral authority. One of the consequences for that role to remain inherent in the teacher is that the teacher must have the ability to relate and communicate with other people. In this social responsibility, teachers in suburban areas have a very good position in society so that they are accepted as a noble profession in society. Of course this is a plus for the social competence of teachers.

The responsibility of the teacher's personality in the periphery can be seen in the teacher who is patient, calm, responsible, sincere, respectful of others, friendly, and initiative [29]. In distance learning of PE lessons, the responsibility of the personality of teachers in suburban areas is quite good. Research on the attitude of responsibility in $\mathrm{PE}$ has actually increased over the last two decades. The application of the attitude of responsibility is often carried out by the teaching profession.

\section{CONCLUSION}

PE teacher groups in urban areas have more responsibilities related to pedagogical, professional, social, and personality responsibilities in implementing distance learning during the COVID-19 pandemic than teachers in suburban areas. This happens because of the support of teaching facilities and good information technology in urban areas which are located in the city center and the center of government as well as the call of responsibility as a teaching profession. However, the responsibility of teachers in the suburbs, although not as good as in urban areas, has a high value of social responsibility considering that the teaching profession in the periphery is still considered a noble profession that has considerable moral authority. The attitude of teacher responsibility is still considered as one of the appropriate and effective pedagogical approaches in implementing distance learning.

\section{ACKNOWLEDGMENTS}

We would like to thank all the teachers involved in the study, namely PE teachers in Jogja City and Gunungkidul Regency. This work was supported by a research grant from YSU with number 35/Penel.UPTUNY-DIPA/UN34.21/2021.

\section{REFERENCES}

[1] González-Calvo, G., R. A. Barba-Martín, D. Bores-García, and V. Gallego-Lema. (2020). “Aprender a Ser Docente sin Estar en las Aulas: La COVID-19 Como Amenaza al Desarrollo Profesional del Futuro Profesorado." International and Multidisciplinary Journal of Social Sciences 9(2): 152-177. doi:10.17583/rimcis.2020.5783

[2] Burki, T. K. (2020). "COVID-19: Consequences for Higher Education." The Lancet Oncology 21 (6): 758. doi:10.1016/S14702045(20)30287

[3] Chick, R. C., G. T. Clifton, K. M. Peace, B. W. Propper, D. F. Hale, A. A. Alseidi, and T. J. Vreeland. (2020). "Using Technology to Maintain the Education of Residents during the COVID-19 Pandemic."Journal of Surgical Education 77 (4): 729-732. doi:10.1016/j.jsurg.2020.03.018

[4] McPhail, A., and H. Lawson. (2020). School Physical Education and Teacher Education Collaborative Redesign for the $21 \mathrm{st}$ Century. Routledge Studies in Physical Education and Youth Sport. London and New York: Routledge

[5] Crawford, J., K. Butler-Henderson, J. Rudolph, B. Malkawi, M. Glowatz, R. Burton, P. Magni, and S. Lam. (2020). "COVID-19: 20 Countries' Higher Education Intra-Period Digital Pedagogy Responses."Journal of Applied Learning \& Teaching 3 (1): 1-20. doi:10.37074/jalt.2020.3.1.7

[6] Utomo, M. N. Y., Sudaryanto, M., \& Saddhono, K. (2020). Tools and Strategy for Distance Learning to Respond COVID-19 Pandemic in Indonesia. Ingenierie Des Systemes d'Information, 25(3), https://doi.org/10.18280/isi.250314

[7] Koesnandar, A. (2020). Pengembangan Model Pembelajaran Inovatif Berbasis Teknologi Informasi dan Komunikasi. Kwangsan: Jurnal Teknologi Pendidikan, 8(1), 33. https://doi.org/10.31800/jtp.kw.v8n1.p33--61 
[8] J Adedoyin, O. B., \& Soykan, E. (2020). Covid-19 pandemic and online learning: the challenges and opportunities. Interactive Learning Environments. Routledge. https://doi.org/10.1080/10494820.2020.1813180

[9] Moorhouse, B. L. (2020). "Adaptations to a Face-to-face Initial Teacher Education Course 'Forced' Online Due to the COVID-19 Pandemic." Journal of Education for Teaching 1-3. doi:10.1080/ 02607476.2020 .1755205

[10] Wirawan, B., \& Tambunan, J. R. (2018). Challenges on Java's small city spatial planning. In IOP Conference Series: Earth and Environmental Science (Vol. 158). Institute of Physics Publishing. https://doi.org/10.1088/1755-1315/158/1/012054

[11] Elmagd, M. A. (2020). Sports and physical activity during (COVID-19) pandemic. International Journal of Physical Education, Sports and Health, 7 (3)(May), 82-84.

[12] Pozo, P., Grao-Cruces, A., \& Pérez-Ordás, R. (2018). Teaching personal and social responsibility modelbased programmes in physical education: A systematic review. European Physical Education Review, 24(1), 56-75. doi:10.1177/1356336X16664749

[13] Hellison, Don. (2011). Teaching personal and social responsibility through physical activity (3rd ed.). Champaign, IL: Human Kinetics.

[14] Rosmawati, R., Ahyani, N., \& Missriani, M. (2020). Pengaruh Disiplin dan Profesionalisme Guru terhadap Kinerja Guru. Journal of Education Research, 1(3), 200-205. https://doi.org/10.37985/jer.v1i3.22

[15] Fernández, M. \& Espada, M. (2021). Knowledge, Education and Use of Teaching Styles in Physical Education. International Journal of Instruction, 14(1), 379-394. https://doi.org/10.29333/iji.2021.14122a

[16] Perdana, N. S. (2018). Implementasi Peranan Ekosistem Pendidikan Dalam Penguatan Pendidikan Karakter Peserta Didik. Refleksi Edukatika: Jurnal Ilmiah Kependidikan, 8(2). https://doi.org/10.24176/re.v8i2.2358

[17] Welsh, R. O., \& Swain, W. A. (2020). (Re)Defining Urban Education: A Conceptual Review and Empirical Exploration of the Definition of Urban Education. Educational Researcher, 49(2), 90-100. https://doi.org/10.3102/0013189X20902822

[18] Adrian, Y., \& Agustina, R. L. (2019). Kompetensi Guru di Era Revolusi Industri 4. Lentera: Jurnal Pendidikan, 14(2), 175-181. https://doi.org/10.33654/jpl.v14i2.907

[19] Deligiannidou, T., Athanailidis, I., Laios, A., \& Stafyla, A. (2020). Determining effective leadership qualities of a school principal from the perception of PE teachers in Greece. Journal of Physical Education and Sport, 20, 2126-2135. https://doi.org/10.7752/jpes.2020.s3286

[20] Winarni, S., \& Lismadiana. (2020). Kompetensi guru pendidikan jasmani olahraga dan kesehatan ditinjau dari usia dan jenis sekolah. Jurnal Pendidikan Jasmani Indonesia, 16 (1), 101-114. Retrieved from https://journal.uny.ac.id/index.php/jpji

[21] Mustofa, T. (2020). Kompetensi Sosial Guru Profesional. Jurnal Pendidikan Agama Dan Keagaman Islam, 1(1), 22-27.

[22] Meilia, M., \& Murdiana, M. (2019). Pendidik Harus Melek Kompetensi Dalam Menghadapi Pendidikan Abad Ke21. Kordinat: Jurnal Komunikasi Antar Perguruan Tinggi Agama Islam, 18(2), https://doi.org/10.15408/kordinat.v18i2.11501

[23] BPKP. (2017). Profil Kabupaten Gunungkidul. Retrieved from http://www.bpkp.go.id/diy/konten/835/Profil-KabupatenGunungkidul

[24] Warren, C. A., \& Venzant Chambers, T. T. (2020, June 1). The Imperative of Social Foundations to (Urban) Education Research and Practice. Educational Researcher. SAGE Publications Inc. https://doi.org/10.3102/0013189X20923289
[25] Kok, M., Komen, A., van Capelleveen, L., \& van der Kamp, J. (2020). The effects of self-controlled video feedback on motor learning and self-efficacy in a Physical Education setting: an exploratory study on the shot-put. Physical Education and Sport Pedagogy, 25(1), 49-66. https://doi.org/10.1080/17408989.2019.1688773

[26] Legowo, B., Kusharjanta, B., Sutomo, A. D., \& Wahyuningsih, D. (2019). Increasing Competency 4C using The G-Suite Application for Education. International Journal of Active Learning, 4(2), $168-171$.

[27] Abidin, Z., Hudaya, A., \& Anjani, D. (2020). Efektivitas Pembelajaran Jarak Jauh Pada Masa Pandemi Covid-19. Research and Development Journal of Education, 1(1), 131. https://doi.org/10.30998/rdje.v1i1.7659

[28] Raibowo, S., Nopiyanto, Y. E., \& Muna, M. K. (2019). Pemahaman Guru PJOK Tentang Standar Kompetensi Profesional. Journal Of Sport Education (JOPE), 2(1), 10. https://doi.org/10.31258/jope.2.1.10-15

[29] Juhadi, Indriyanti A., Azmi A.U. (2018). Fenomena Urban Sprawl Jabodetabek. CV Fastindo. Tembalang Semarang. 